\title{
PENGARUH MODEL PEMBELAJARAN BERBASIS MASALAH TERHADAP KEMAMPUAN BERPIKIR KRITIS SISWA PADA MATERI LARUTAN PENYANGGA
}

\author{
Mawaddatun Warahmah ${ }^{1^{*}}$, Rahmawati ${ }^{2}$, Jeckson Siahaan ${ }^{3}$ \\ ${ }^{123}$ Program Studi Pendidikan Kimia, Universitas Mataram. Jalan Majapahit No. 62 \\ Mataram, NTB 83112, Indonesia. \\ * Coressponding Author. E-mail: mawaddatunw32@gmail.com
}

Received: 15 November 2020

Accepted: 30 Mei 2021

Published: 30 Mei 2021

doi: 10.29303/cep.v4i1.2200

\begin{abstract}
Abstrak
Penelitian ini bertujuan untuk mengetahui pengaruh model pembelajaran berbasis masalah terhadap kemampuan berpikir kritis siswa pada materi larutan penyangga. Penelitian ini merupakan quasi eksperimen denga posttest control group design. Populasi penelitian ini adalah siswa kelas XI MS SMA Negeri 1 Kediri. Metode pengambilan sampel menggunakan metode random sampling, menghasilkan kelas XI MS 1 sebagai kelas eksperimen dan kelas XI MS 2 sebagai kelas kontrol. Kelas eksperimen diberi perlakuan dengan menggunakan model pembelajaran berbasis masalah dan pada kelas kontrol diberi perlakuan dengan menggunakan model pembelajaran konvensional dalam bentuk ceramah dan tanya jawab. Uji hipotesis menggunakan Uji Non-Parametris Mann-Whitney $U$ Test yang mengacu pada nilai $\mathrm{Z}_{\text {tabel }}(\mathrm{Z} \alpha)$ pada taraf signifikan 0,05 uji pihak kanan, diperoleh $Z_{\text {hitung }}$ $(1,92)>Z_{\text {tabel }}(1,64)$ yang berarti Ha diterima dan Ho ditolak. Jadi, penerapan model pembelajaran berbasis masalah memberikan pengaruh yang lebih baik daripada pembelajaran konvensional terhadap kemampuan berpikir kritis siswa pada materi larutan penyangga.
\end{abstract}

Kata Kunci: Problem-based learning, berpikir kritis, larutan penyangga

\section{The Effect of Problem Based Learning Models on Students 'Critical Thinking Ability in Buffer Solution Material}

\begin{abstract}
This study aims to determine the effect of problem-based learning models on students' critical thinking skills in the buffer solution material. This study is a quasi-experimental study with a posttest control group design. The population of this study were students of class XI MS SMA Negeri 1 Kediri. The sampling method used random sampling method, resulting in class XI MS 1 as the experimental class and class XI MS 2 as the control class. The experimental class was treated using a problembased learning model and the control class was treated using a conventional learning model in the form of lectures and questions and answers. Hypothesis testing using the Mann-Whitney U-Test NonParametric Test which refers to the $Z_{\text {table }}(Z \alpha)$ value at a significant level of 0.05 , obtained $Z_{\text {count }}$ (1.92)> $Z_{\text {table }}(1.64)$ which means that Ha is accepted and Ho was rejected. So, the application of the problem-based learning model has a better effect than conventional learning on students' critical thinking skills in the buffer solution material.
\end{abstract}

Keywords: problem-based learning, critical thinking, buffer solution.

\section{PENDAHULUAN}

Pembelajaran dikatakan berhasil jika diselenggarakan secara interaktif, inspiratif, menyenangkan, menantang, dan memotivasi siswa untuk berpartisipasi aktif, serta memberikan ruang yang cukup bagi prakarsa, kreativitas, dan kemandirian sesuai dengan bakat, minat, dan perkembangan fisik serta psikologis siswa (Suwarsi, dkk., 2018., Rosyid, 


\title{
Chemistry Education Practice, 4 (1), 2021 - 74
}

\author{
Warahmah, Rahmawati, Siahaan
}

2019). Namun dalam prosesnya, pembelajaran di sekolah hanya memberikan waktu yang sedikit bagi siswa untuk mengembangkan kemampuan berpikir kritisnya (critical thinking) (Haryadi, 2016).

Kemampuan berpikir kritis memberikan arahan yang tepat dalam berpikir dan bekerja, membantu menentukan keterkaitan sesuatu dengan yang lainnya dengan akurat, sehingga kemampuan berpikir kritis siswa harus dikembangkan sedini mungkin, baik pada jenjang sekolahdasar maupun sekolah menengah (Sastrika, 2013., Loka \& Anwar, 2019). Berpikir kritis memungkinkan siswa untuk mempelajari masalah secara sistematis, menghadapi banyak rintangan dengan cara yang terorganisasi, merumuskan pertanyaan inovatif, dan merancang solusi yang tepat atas permasalahan yang dihadapi (Muspita, 2013., Qomariyah, 2017). Pengembangan proses mental seperti pengembangan kemampuan berpikir kritis siswa sangat penting didalam pembelajaran kimia (Loka \& Anwar, 2019).

Ilmu kimia merupakan salah satu cabang dari ilmu pengetahuan alam (IPA) yang mempelajari tentang gejala alam dan berbagai peristiwanya dengan serangkaian kegiatan observasi dan eksperimen, sehingga diperoleh konsep-konsep baru dan teori-teori tentang sifat materi, struktur materi, perubahan materi, hukum dan prinsip yang mendeskripsikan perubahan materi. Konsep-konsep ilmu kimia bersifat konkrit, abstrak, dan prosedural, sehingga diperlukan pemahaman yang baik untuk mempelajarinya (Priyasmika, 2019, Ariani, dkk., 2020).

Salah satu model pembelajaran yang dapat meningkatkan kemampuan berpikir adalah model pembelajaran yang mampu mendorong berlangsungnya pembelajaran dalam konteks riil, salah satunya adalah model Problem Based Learning (PBL) (Apriyani, 2017., Qomariyah, 2017., Laksmiwati, dkk., 2019). Pembelajaran PBL memacu siswa untuk berpikir kritis dan kreatif serta mengembangkan ide-ide sehingga bisa memecahkan masalah melalui serangkaian eksperimen (Halim, 2017).

Berdasarkan observasi yang dilakukan model pembelajaran yang paling banyak digunakan di SMA Negeri 1 Kediri untuk materi kimia adalah konvensional (ceramah) sehingga mengakibatkan siswa kurang aktif di kelas dan partisipasi siswa dalam pembelajaran menjadi rendah. Hasil wawancara dengan siswa yang mengungkapkan fakta bahwa banyak diantara siswa merasa bosan dengan pelajaran yang diberikan, sulit memahami materi pelajaran, kurang mampu berpikir kritis, dan kurang minat untuk berperan aktif dalam proses pembelajaran. Fenomena tersebut berdampak pada rendahnya minat belajar siswa.

Wulandari (2020) meneliti tentang pengaruh model problem based learning terhadap keterampilan berpikir kritis siswa materi keanekaragaman hayati, hasil uji deskriptif untuk kelas eksperimen (PBL) diperoleh data tes awal dengan nilai terendahnya adalah 50, nilai tertingginya adalah 75 , dan ratarata nilainya adalah 62,10 . Pada tes akhir kelas eksperimen nilai terendahnya adalah 60 , nilai tertingginya adalah 90 , dan rata-rata nilainya adalah 76,61. Sedangkan hasil uji deskriptif untuk kelas kontrol diperoleh data untuk tes awal, dimana pada tes awal dapat dilihat nilai terendah untuk kelas kontrol adalah 50, nilai tertingginya adalah 70 , dan rata-rata nilainya dalah 59, 67. Pada tes akhir untuk kelas kontrol nilai terendahnya adalah 50, nilai tertingginya 80 dan rata nilainya adalah 66,83 . Sehingga dapat diketahui bahwa model pembelajaran Problem Based Learning (PBL) memberikan pengaruh yang signifikan untuk meningkatkan kemampuan berpikir kritis siswa khususnya pada materi keanekaragaman hayati di SMA Unggul Negeri 4 Palembang.

Pembelajaran dengan model (PBL) pada materi kimia belum diterapkan di SMA Negeri 1 Kediri, sehingga perlu dilakukan penerapan PBL untuk meningkatkan kemampuan berpikir kritis siswa kelas XI MS Tahun Pelajaran 2019/2020 pada materi larutan penyangga.

\section{METODE}

Penelitian ini akan dilaksanakan di SMA Negeri 1 Kediri, pada bulan Februari 2020. Penelitian ini termasuk jenis penelitian eksperimen semu atau Quasi Experiment karena peneliti tidak dapat mengontrol semua variabel luar yang mempengaruhi jalannya eksperimen yang dikembangkan dalam penelitian ini adalah PBL untuk meningkatkan kemampuan berpikir kritis siswa. Sampel yang digunakan terdiri dari 2 kelas, satu kelas untuk kelas eksperimen dan satu kelas lainnya sebagai kelas kontrol. Kelas Sampel yang terpilih sebagai kelas eksperimen adalah kelas XI MS 1 dengan jumlah siswa 35 orang dan kelas XI MS 2 dengan jumlah siswa 36 orang sebagai kelas kontrol. 
Pada kelas kontrol digunakan model pembelajaran konvensional yaitu ceramah dan tanya jawab, dan pada kelas eksperimen menggunakan model pembelajaran berbasis masalah (PBL) yang masing-masing dilakukan 4 kali pertemuan dengan alokasi waktu 2 jam pelajaran ( 2 x 45 menit). Pada pertemuan ke-4 dilakukan posttest dengan test yang sama bentuk essay yang terdiri dari 6 butir soal.

Analisis data menggunakan statistik Aiken's V untuk memverifikasi validitas isi soal posttest, rumus korelasi point biseral untuk memverifikasi validitas butir soal dan rumus KR-20 untuk mengetahui reliabilitas soal. Pengujian hipotesis menggunakan Uji Hipotesis Non-Parametris Mann-Whitney U-Test.

\section{HASIL DAN PEMBAHASAN}

Data hasil belajar siswa yang diukur dengan kemampuan menjawab soal-soal materi larutan penyangga. Skor yang dapat diperoleh siswa berkisar antara 0-99. Berdasarkan data yang diperoleh perbandingan skor kedua kelas dapat dilihat pada Tabel 1.

Tabel 1. Perbandingan Kemampuan Berpikir Kritis Siswa

\begin{tabular}{lcr}
\hline & $\begin{array}{l}\text { Kelas } \\
\text { Eksprimen }\end{array}$ & $\begin{array}{l}\text { Kelas } \\
\text { Kontrol }\end{array}$ \\
\hline Nilai Tertinggi & 85 & 83 \\
Nilai Terendah & 28 & 23 \\
Rata-Rata & 59 & 51 \\
\hline
\end{tabular}

Pada tabel 1, dapat dilihat bahwa skor tertinggi, skor terendah, dan skor rata-rata lebih tinggi pada kelas eksprimen dibanding kelas kontrol. Hal ini sesuai dengan penelitian Munandar (2017) di SMA Negeri 1 Parepare, menyimpulkan bahwa persentase karakter siswa meningkat dari siklus I ke siklus II. Sementara berdasarkan hasil analisis statistik deskriptif untuk hasil belajarsiswa menunjukkan bahwa pada siklus I diperoleh nilai rata-rata 67,02 sedangkan pada siklus II diperoleh nilai rata-rata yaitu 75,61. Dari hasil analisis data ini dapat ditarik kesimpulan bahwa model PBM dapat mengembangkan nilai-nilai karakter siswa kelas XI IPA 3 SMA Negeri 1 Parepare pada materi pokok larutan asam basa.

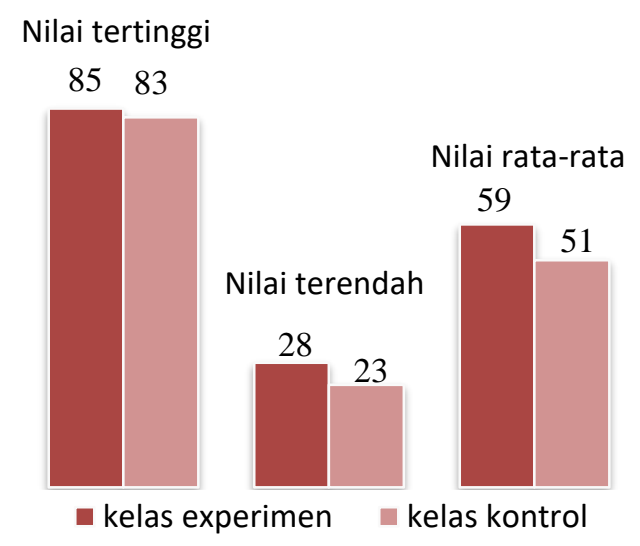

\section{Gambar 1. Hasil posttest siswa kelas eksperimen dan kelas kontrol}

Berdasarkan Gambar 1, terlihat bahwa nilai rata-rata kemampuan berpikir kritis siswa kelas eksperimen lebih tinggi dibandingkan kelas kontrol. Hal ini didukung oleh penelitian Wulandari (2020) dan Fitriani, dkk. (2019), hasil uji deskriptif yang telah dilakukan menunjukkan terjadi peningkatan nilai rata-rata pada kelas eksperimen yaitu sebesar 14,1 (dari 62,10 ke 76,6), disebabkan karena di dalam langkahlangkah model pembelajaran PBL siswa tidak hanya semata-mata menerima materi yang diberikan oleh guru, tetapi mereka ikut berperan langsung dalam proses pembelajaran, selain itu mereka juga berupaya sendiri untuk mencari informasi guna memecahkan permasalahan yang disediakan oleh oleh guru di dlam LKS, seperti melakukan pengamatan di luar kelas, dan mencari informasi yang relevan dari berbagai referensi.

Penggunaan model pembelajaran PBL dapat meningkatkan nilai rata-rata aktivitas siswa pada setiap pertemuan pembelajaran.Hal ini dikarenakan siswa telah dapat menerapkan tahapan-tahapan pembelajaran PBL. Menurut Laksmiwati, dkk. (2019), melalui permasalahan yang diberikan dalam PBL, siswa dapat lebih terlibat untuk menyelesaikan permasalahan yang diberikan dan terlibat untuk menggunakan keterampilan berpikir kritis.

Berbeda dengan kelas kontrol, nilai ratarata aktivitas siswa pada kelas kontrol lebih rendah dibandingkan dengan nilai rata-rata aktivitas siswa kelas eksperimen. Hal ini disebabkan karena pembelajaran yang dilakukan berpusat pada guru sehingga siswa tidak dapat menggunakan kemampuannya secara optimal. Selain itu siswa pada kelas kontrol hanya mendengarkan penjelasan dari guru yang 
menyebabkan siswa mudah merasa bosan, mudah mengantuk, dan lain sebagainya.

Nilai posttest digunakan untuk menguji hipotesis (dengan uji t), namun karena sampel tidak terdistribusi dengan normal maka hipotesis diuji menggunakan uji $Z$. Hasil pengujian menunjukkan nilai $Z_{\text {hit }} 1,92$ dan nilai $Z_{\text {tab }} 1,64$, berarti $Z_{\text {hit }}>Z_{\text {tab }}$ sehingga Ha diterima dan Ho ditolak, maka model PBL dapat meningkatkan kemampuan berpikir kritis siswa kelas XI MS SMA Negeri 1 Kediri.

\section{SIMPULAN}

Berdasarkan data hasil penelitian dan pembahasan, maka dapat disimpulkan bahwa penerapan model PBL memberikan pengaruh yang lebih baik terhadap kemampuan berpikir kritis siswa SMA Negeri 1 Kediri kelas XI MS Tahun Pelajaran 2019/2020 pada materi larutan penyangga dibandingkan dengan pembelajaran konvensional.

\section{DAFTAR PUSTAKA}

Apriyani, L., Nurlaelah, I., \& Setiawati, I. (2017). Penerapan model PBL untuk meningkatkan keterampilan berpikir kritis ditinjau dari kemampuan akademik siswa pada materi biologi. Quagga: Jurnal Pendidikan dan Biologi, 9(01).

Ariani, S., Effendy, E., \& Suharti, S. (2020). Model Mental Mahasiswa Pada Fenomena Penghilangan Karat Melalui Elektrolisis. Chemistry Education Practice, 3(2), 5562.

Fitriani, F., Loka, I. N., Junaidi, E., \& Al-Idrus, S. W. (2019). Studi Komparasi Pengaruh Antara Model Pembelajaran Problem Based Learning (PBL) dan Self Regulated Learning (SRL) Terhadap Hasil Belajar Kimia. Chemistry Education Practice, 2(1), 6-11.

Halim, A., Suriana., Mursal. 2017. "Dampak Problem Based Learning terhadap Pemahaman Konsep Ditinjau Dari Gaya Berpikir Siswa Pada Mata Pelajaran Fisika". Jurnal Penelitian \& Pengembangan Pendidikan Fisika. 3 (1): 1-10.

Haryadi, Sandi., Ery Tri Djatmiko., Punadji Setyosari. 2016. "Pembelajaran Tematik dalam Menumbuhkan Sikap Ilmiah dan Keterampilan Berpikir Kritis Siswa SD". Jurnal pendidikan. 1 (1): 1-10.

Laksmiwati, D., Hadisaputra, S., \& Siahaan, J. (2019). Pengembangan Modul Praktikum
Kimia Berbasis Problem Based Learning Untuk Kelas XI SMA. Chemistry

Education Practice, 1(2), 36-41.

Loka, I. N., \& Anwar, Y. A. S. (2019). Pengaruh Model Pembelajaran Inkuiri Terbimbing Dengan Metode Pembelajaran Terpadu Kemampuan Berpikir Kritis. Chemistry Education Practice, 2(2), 29-35.

Munandar, Haris., Hijrah Syam. 2017. "Penerapan Model Pembelajaran Berbasis Masalah Pada Materi Pokok Asam Basa Untuk Mengembangkan Nilai-Nilai Karakter Siswa Kelas XI IPA 3 SMA Negeri 1 Parepare”. Jurnal Sainsmat. 6 (2) : 10-17.

Muspita, Z., Lasmawan, W., \& Sariyasa, S. (2013). Pengaruh Model Pembelajaran Berbasis Masalah Terhadap Kemampuan Berfikir Kritis, Motivasi Belajar, dan Hasil Belajar IPS Siswa Kelas VII SMPN 1 Aikmel (Doctoral dissertation, Ganesha University of Education).

Priyasmika, Rendy. 2019. "Perbandingan Strategi Inkuiri Terbimbing Dengan Problem Solving Terhadap Pemahaman Konseptual dan Algoritma Siswa Dengan Kemampuan Berpikir Ilmiah Rendah". Jurnal ED-Humanistics. 4 (1): 485-494.

Qomariyah, E. N. (2017). Pengaruh Problem Based Learning terhadap Kemampuan Berpikir Kritis IPS. Jurnal Pendidikan dan Pembelajaran (JPP), 23(2), 132-141.

Rosyid, M. Z., Mansyur, M., IP, S., \& Abdullah, A. R. (2019). Prestasi Belajar. Literasi Nusantara.

Sastrika, Ida Ayu Kade., I Wayan Sadia., I Wayan Muderawan. 2013. "Pengaruh Model Pembelajaran Berbasis Proyek Terhadap Pemahaman Konsep Kimia dan Keterampilan Berpikir Kritis”. Jurnal Program Pascasarjana Universitas Pendidikan Ganesha. 3 (1): 1-10.

Suwarsi, S., Mukti, Z., \& Prabowo, A. (2018, February). Meningkatkan Keterampilan HOTS Siswa melalui Permainan Kartu Soal dalam Pembelajaran PBL. In PRISMA, Prosiding Seminar Nasional Matematika (Vol. 1, pp. 248-255).

Wulandari, Rizki., Sri Wardhani., Sulton Nawawi. 2020. "Pengaruh Model Problem Based Learning Terhadap Keterampilan Berpikir Kritis Siswa Materi Keanekaragaman Hayati”. Jurnal Pendidikan. 3 (1): 45-53. 